\title{
Pelayanan Komunikasi Pemerintahan Dalam Pemberitaan Kebijakan Pemerintah Daerah Kepada Stakeholder di Kalimantan Selatan
}

\author{
Sarwani Sarwani \\ Program Studi Ilmu Komunikasi Fakultas Ilmu Sosial dan Ilmu Politik \\ Universitas Lambung Mangkurat Banjarmasin \\ Email: sarwani_komunikasi@ulm.ac.id
}

\begin{abstract}
This study was conducted in the midst of the lack of studies on local government communication in developing countries. Existing studies tend to attribute performance in this area to central government. The contribution of this study is related to exploring the practice of government communication in the context of local government in countries towards democracy. The author uses the communication of the local government of South Kalimantan Province in its services to stakeholders as a case study. The results of the analysis of various documents, observations and in-depth interviews related to the communication performance of local government in South Kalimantan from January to October 2020 were compiled and analyzed using Miles and Huberman data analysis techniques. In conclusion, the results of the study show that the quality of local government communication is influenced by various factors, both structural and management. Although management factors remain important, in the case of South Kalimantan, structural factors have more influence on local government communications. While the communication performance of local government has not involved active participation from the bottom, it is more elite-oriented than public-oriented. Local government officials are less responsive and still communicate downward, so that the ideas of professionalizing local government communication are still limited to expectations rather than reality. This study recommends that local government communication can be effective if it is participatory, ie has a vision and mission of community empowerment and citizen involvement in participation for local government policy planning and implementation.
\end{abstract}

Keywords: Service, Government Communication, Local Government, Participatory, Stakeholder, South Kalimantan.

\begin{abstract}
Abstrak
Studi ini dilakukan ditengah-tengah masih sedikitnya studi mengenai komunikasi pemerintahan pemerintah daerah di negara negara berkembang. Studi yang ada cenderung mengkaitkan kinerja dalam bidang ini dengan pemerintah pusat. Kontribusi studi ini terkait penggalian praktik komunikasi pemerintahan dalam konteks pemerintah daerah di negara-negara menuju demokratis. Penulis menggunakan komunikasi pemerintahan pemerintah daerah Provinsi Kalimantan Selatan dalam pelayanannya kepada stakeholder sebagai kasus studi. Hasil analisis berbagai dokumen, pengamatan dan wawancara mendalam yang berkaitan dengan kinerja komunikasi pemerintahan pemerintah daerah di Kalimantan Selatan dari Januari hingga oktober 2020 dikompilasi, dianalisis dengan menggunakan teknik analisis data Miles dan Huberman. Kesimpulannya, hasil studi menunjukkan bahwa kualitas komunikasi pemerintah daerah dipengaruhi oleh berbagai faktor baik struktural maupun manajemen. Meskipun faktor manajemen tetap penting, dalam kasus Kalimantan Selatan, faktor struktural lebih berpengaruh pada komunikasi pemerintah daerah. Sementara kinerja komunikasi pemerintah daerah belum melibatkan partisipasi aktif dari bawah, lebih berorientasi elit daripada berorientasi publik. Para pejabat pemerintah daerah kurang responsif dan masih downward communication, sehingga ide-ide profesionalisasi komunikasi pemerintah daerah masih terbatas pada harapan daripada kenyataan. Studi ini merekomendasikan bahwa komunikasi pemerintah daerah dapat efektif jika partisipatif, yakni memiliki visi dan misi pemberdayaan masyarakat dan keterlibatan warga negara dalam partisipasi untuk perencanaan kebijakan pemerintah daerah dan implementasinya.
\end{abstract}

Kata Kunci: Pelayanan, komunikasi pemerintahan; pemerintah daerah, partisipatif, Stakeholder, Kalimantan Selatan. 


\section{A. PENDAHULUAN}

Disentralisasi membuka peluang otonomi daerah yang seharusnya membawa angin segar bagi pemerintahan daerah yang baik. Namun praktiknya perilaku pemerintah daerah tidak sesuai dengan prinsip responsif, transparan, akuntabel yang merupakan tujuan dari disentralisasi (Aspinall \& Fealy, 2003; Rasyid, 2003). Walaupun praktik-praktik tidak demokratis bukanlah hal baru dalam politik Indonesia, dari sisi optimis, desentralisasi masih menumbuhkan benih harapan. Harapan ini muncul dalam budaya politik baru yang lebih demokratis dan egaliter bahkan ke tingkat desa, sehingga kekuasaan menjadi semakin tersebar dan diperoleh dalam iklim persaingan yang adil. Mekanisme tradisional "Rembug Desa" meski terdesak masih eksis, di pedesaan di nusantara ini. "Rembug desa" sebagai ruang musyawarah untuk menemukan solusi dalam menyelesaikan konflik di desa yang melibatkan para pemimpin desa dan anggota masyarakat dalam posisi yang relatif sama. Iklim ini sangat substansial dan diperlukan ketika demokrasi lokal akan digunakan sebagai dasar untuk tata pemerintahan yang baik dan komunikasi dalam masyarakat (Prasetyo, 2010; Ibrahim, 2020, hal. 140).

Kondisi penyelenggaraan pemerintahan pasca lahirnya undang-undang nomor 22 tahun 1999 tentang pemerintahan daerah, mengisyaratkan empat variabel yang harus dijalankan yakni: demokratisasi, pelayanan, pemberdayaan dan transparansi. Dibidang pelayanan muncul fenomena layanan komunikasi pemerintahan dalam pemberitaan kebijakan pemerintah daerah pemerintah provinsi Kalimantan Selatan kepada stakeholdernya yang dibayangi kesan negatif. Padahal pemerintah daerah yang mendapat mandat dari masyarakat sudah selayaknya memberikan pelayanan komunikasi pemerintahan yang maksimal dan optimal kepada stakeholdernya. Secara organisatoris, sangat mungkin pemerintah daerah melakukan hal tersebut mengingat personal sarana dan prasarana telah tersedia. Bahkan ada struktur khusus yang ditugasi untuk menjalankannya. Setiap personal yang berada di struktur tersebut sudah selayaknya mempunyai talenta sesuai tupoksinya. Sehingga setiap informasi mampu diolah secara menarik. Setiap informasi yang telah diolah, oleh unit yang lain mampu disampaikan melalui berbagai media, baik yang bersifat personal, kelompok, massa dan media sosial.

Studi awal yang telah dilakukan penulis pada pemerintah daerah provinsi Kalimantan selatan menunjukkan bahwa pelayanan komunikasi pemerintahan dalam pemberitaan kebijakan pemerintah daerah telah dilaksanakan melalui berbagai program seperti pertemuan dengan pemimpin redaksi media lokal, kerjasama pengisian siaran di televisi, penerbitan tabloid, layanan publik secara online dan sebagainya. Kemudian juga disampaikan kebijakan pemerintah daerah melalui pertemuan-pertemuan yang melibatkan Gubernur maupun wakilnya, dimana mereka menyampaikan pidatonya. Dari studi pendahuluan didapat kesan, komunikasi pemerintahan pemprov tentang kebijakannya kental dengan kepentingan pemerintah dan mungkin sedikit sekali mengungkap hal hal negatif atau risiko yang bisa muncul dengan terbitnya kebijakan pemprov tersebut.

Dari uraian diatas dapat ditarik sebuah inti permasalahan yakni komunikasi pemerintahan dalam pemberitaan kebijakan pemerintah daerah propinsi Kalimantan Selatan kepada stakeholdernya masih mengalami hambatan. Sehingga menimbulkan pertanyaan apakah semua stakeholder pemprov Kalimantan selatan sudah mendapatkan informasi dan penjelasan yang optimal tentang kebijakannya.

Di pemprov kalimantan selatan ada struktur biro administrasi pimpinan dan Dinas kominfo yang merupakan "leading Sector" untuk mengelola komunikasi pemerintahan. Stakeholder merupakan obyek komunikasi pemerintahan yang juga sekaligus sebagai subyeknya. Mereka berhak mengetahui, mengerti dan mengawasi konten program-program tersebut terutama yang isinya tentang kebijakan pemda propinsi Kalimantan Selatan. Bahkan mereka berhak untuk menilai bagaimana kualitas pelayanan komunikasi pemerintahan pemprop dalam pemberitaan kebijakannya kepada stakeholder.

Secara umum studi ini bertujuan terciptanya teknologi manajemen berupa rekomendasi pelayanan komunikasi pemerintahan dalam pemberitaan kebijakan pemda kepada stakeholdernya. Khususnya adalah Menyusun rekomendasi pelayanan komunikasi pemerintahan dalam pemberitaan kebijakan pemda provinsi Kalimantan selatan kepada stake holdernya.

\section{B. PELAKSANAAN DAN METODE}

Satu model umum tentang proses komunikasi pemerintahan diawali oleh pengirim (administrator atau manajer pemerintah) yang berusaha berkomunikasi dengan aparatur birokrasi, masyarakat dan organisasi lain. Untuk itu dipilih seperangkat informasi sebagai pesan yang ingin dikirimkan (ideation). Ketika hendak mengirim informasi, pengirim menterjemahkan informasi tersebut dalam bentuk kata-kata, tanda-tanda, atau lambang-lambang yang tepat yang diharapkan dapat dengan mudah dipahami oleh penerima dan diharapkan memiliki efek terhadap orang lain. Ekspresi gagasan atau ide dalam bentuk verbal (lisan dan tulisan), atau nonverbal (bahasa isyarat, ekpresi wajah, gerakan, atau gambar), disebut 
pesan (message). Pesan yang disampaikan dapat berupa kebijakan-kebijakan, prosedur-prosedur, peraturan-peraturan, keputusan-keputusan.

Jadi komunikasi pemerintahan pada hakekatnya merupakan proses penyebaran dan pertukaran informasi di dalam dan dengan luar organisasi. Melalui komunikasi pemerintahan, maka eksekutif pemerintahan bertukar dan membagi informasi dengan yang lain, yaitu dengan legislatif, dengan staf, dengan pelaku bisnis, dan dengan masyarakat. Melalui komunikasi, eksekutif pemerintah atau administrator atau manajer pemerintah bermaksud untuk mempengaruhi sikap (attitude), pemahaman (understanding), dan perilaku (behavior) birokrasi dan masyarakat. Dengan demikian, tiap orang yang terlibat dalam penyelenggaraan pemerintahan demokratis merupakan bagian dari proses komunikasi pemerintahan, baik sebagai sender di satu waktu, dan di waktu lain ia menjadi receiver. Juga merupakan sarana penyaluran masukan sosial ke dalam sistem sosial, dan sarana memodifikasi perilaku, mempengaruhi perubahan, memproduktifkan informasi, sarana untuk mencapai tujuan serta membantu pelaksanaan dan memadukan fungsi-fungsi manajemen (Pearce and Robinson, 1989: 550). Adapun fungsi komunikasi dalam suatu organisasi, termasuk organisasi pemerintah sebagai organisasi nonprofit adalah: fungsi informatif, regulatif, persuasif, dan integratif. Fungsi informatif berarti, komunikasi dipandang sebagai suatu sistem pemrosesan informasi dan kemudian menyebarkannya kepada pihak yang membutuhkan, baik internal maupun eksternal. Fungsi regulatif, berkaitan dengan peraturan-peraturan yang berlaku dalam suatu organisasi. Regulasi dibuat melalui proses komunikasi oleh orang-orang yang berada dalam posisi otoritas pembuat regulasi. Fungsi persuasif dimaksudkan sebagai suatu cara melalui komunikasi dilakukan persuasi kepada orang lain sehingga mereka menerima pesan dan melaksanakannya dengan cara sukarela, tanpa paksaan atau dipaksa.

Komunikasi pemerintahan dalam good governance menekankan ketanggapan (responsiveness), transparansi (transparency), partisipasi (participation), dan akuntabilitas (accountability). Ketanggapan berarti perhatian manajemen publik harus secara konstan, intensif, dan cepat terhadap informasi yang disampaikan secara langsung oleh warga baik kepada birokrasi maupun melalui legislator atau politisi (Denhardt dan Grubbs, 1999: 19; Frederickson, 1984:52); transparansi berarti memberi informasi secara benar, jujur dan adil; partisipasi berarti masyarakat diikutsertakan memberi informasi dalam membuat kebijakan dan berjalannya control sosial; dan akuntabilitas menunjukkan suasana pemerintahan yang bertanggungjawab atas informasi kebijakan dan penyelenggaraan pemerintahan. Informasi-informasi yang penting dalam good governance ialah informasi sektor publik berhubungan dengan penyelenggaraan pemerintahan, hukum, dan administrasi; informasi sektor dunia usaha yang berhubungan dengan pengembangan potensi ekonomi; dan informasi sektor sosial yang berhubungan dengan kegiatan kegiatan sosial dan ekonomi yang tidak dijangkau oleh institusi public dan bisnis. Administrator dalam organisasi pemerintah secara normal ditekankan dari banyak pihak dengan informasional dan sumber data yang mengalir ke dalam jabatan- jabatannya dari atasan mereka, subordinasi, badan-badan lain, kelompok warga, dan publik. Kadang-kadang informasi diterima melalui saluran-saluran formal rutin; pada waktu lain itu menetes ke bawah kepada administrator melalui rute tak diminta.

Hasan (2005) mendefinisikan Komunikasi pemerintahan adalah, penyampaian ide, program, dan gagasan pemerintah kepada masyarakat dalam rangka mencapai tujuan negara (dalam hal ini pemerintah dapat diasumsikan sebagai komunikator dan masyarakat sebagai komunikan, namun dalam suasana tertentu bisa sebaliknya masyarakat berada pada posisi sebagai penyampai idea atau gagasan dan pemerintah berada pada posisi mencermati apa yang diinginkan masyarakat). Dalam kondisi yang demikian pemerintah memiliki kewenangan sekaligus bertanggung jawab untuk mempertimbangkan, bahkan untuk merespon keinginan-keinginan tersebut sesuai dengan aturan dan ketentuan yang berlaku.

Sementara tantangan adaptif dari aktor komunikasi pemerintah daerah jauh melampaui teknologi, mereka menyerukan perlunya struktur dan keterampilan organisasi, pengembangan kapasitas, bentuk-bentuk baru kepemimpinan, transformasi kemitraan publik-swasta. Namun, tantangan dari komunikasi pemerintah daerah di negara-negara berkembang, sebagian besar masih belum dijelajahi. Dalam konteks lokal Kalimantan Selatan, berbagai agensi manusia, kompleksitas faktor struktural dan manajemen, masalah yang berkaitan dengan wilayah ini, memerlukan studi yang terfokus dan pendekatan yang tepat.

Studi ini mempertimbangkan perlunya memperkenalkan pendekatan baru yaitu pendekatan komunikasi pemerintah partisipatif. Berdasarkan prasyarat yang dibuat oleh para peneliti sebelumnya, penelitian ini menambahkan beberapa prasyarat baru yang sejalan dengan tujuan utama desentralisasi: pemerintah daerah yang responsif, transparan, akuntabel, dan baik (Aspinall \& Fealy, 2003; Rasyid, 2003). Studi ini menawarkan model awal untuk Pendekatan Komunikasi Pemerintah Partisipatif untuk konteks lokal Kalimantan Selatan di mana praktik komunikasi pemerintah daerah harus responsif, transparan, akuntabel, terbuka, dan melibatkan warga negara, yang tidak berarti bahwa semua 
kepentingan memiliki dampak yang sama tetapi mereka memiliki peluang nyata untuk diartikulasikan dan dikomunikasikan.

Pelayanan komunikasi pemerintahan berkaitan dengan pelayanan publik. Pelayanan menurut H.A.S. Moenir (2000) adalah suatu proses pemenuhan kebutuhan melalui aktivitas oranglain. Sementara itu Simamora (2001) mengatakan bahwa layanan adalah setiap kegiatan atau manfaat yang ditawarkan suatu pihak kepada pihak lain, yang pada dasarnya tidak berwujud dan tidak mengakibatkan kepemilikan apapun, baik layanan berupa fisik atau tidak. Dari definisi definisi di atas dapat disimpulkan bahwa: pelayanan merupakan suatu kegiatan yang dilakukan oleh seseorang, kelompok atau organisasi dalam memberikan kepuasan kepada masyarakat penggunanya (users). Agus Dwiyanto (2008) mendefinisikan pelayanan publik adalah: "serangkaian aktvitas yang dilakukan oleh birokrasi publik atau penyelenggara pelayanan publik untuk memenuhi kebutuhan warga pengguna". Sedangkan Miftah Thoha (1991) mendefinisikan pelayanan publik adalah "suatu usaha yang dilakukan oleh seseorang/kelompok orang atau institusi tertentu untuk memberikan kemudahan dan bantuan kepada masyarakat dalam rangka mencapai tujuan tertentu. Dari definisi definisi di atas dapat disimpulkan pelayanan publik merupakan suatu upaya memberi manfaat kepada publik melalui barang atau jasa yang diperlukan mereka. Pelayanan publik yang dilakukan oleh institusi pemerintah, bisa diistilahkan pelayanan pemerintah, jika pemberian manfaat tersebut berupa jasa pemberitaan kebijakan pemda, maka pelayanan tersebut dikatakan pelayanan komunikasi pemerintahan. Jadi, pelayanan komunikasi pemerintahan dalam konteks penelitian ini adalah upaya pemda memberi manfaat kepada stakeholdernya dengan memberitakan kebijakannya, dengan pemberitaan yang berbasis stakeholder.

Ada dua sisi kontroversi berkaitan dengan pelayanan pemerintah, di era demokratisasi dan reformasi yaitu; (1) sisi munculnya tuntutan pemerintahan yang betul-betul memberikan pelayanan kepada masyarakat; (2) tuntutan keterbukaan dan transparansi terhadap semua level kebijakan. Ironisnya yang mengedepan dari karakteristik komunikasi pemerintah saat ini adalah, kesibukan pemerintah dalam berbenah diri mengatur dan membagi kepentingan rekan sejawat dan belum sepenuhnya untuk lebih transparan kepada masyarakat atau usersnya. Sistem komunikasi informasi dimana masyarakat dengan mudah mengakses berbagai permasalahan khususnya bidang pemerintahan dari berbagai belahan dunia. Kondisi inilah yang disebut fenomena komunikasi pemerintahan yang kurang menguntungkan dalam konteks dan karakteristik komunikasi pemerintahan yang pada hakikatnya mencakup semua asfek kehidupan.
Penelitian ini mendekati obyek penelitian untuk mengumpulkan data kualitatif secara holistik. Sehingga data yang didapatkan memiliki kualitas yang tinggi. Pengumpulan data primer dilakukan langsung di lapangan (field research) dilapangan. Sementara data skunder dari study kepustakaan (library research). Seluruh gambaran analisis data yang ditemukan dilapangan akan dirangkai menjadi sebuah rekomendasi pelayanan komunikasi pemerintahan dalam pemberitaan kebijakan pemda kepada stakeholdernya dengan didukung oleh data yang ada.

Objek penelitian ini adalah proses dan kegiatan komunikasi pemerintah daerah Kalimantan Selatan. Fokus pengamatan adalah komunikasi pemerintah di bidang layanan publik dari pemerintah daerah Kalimantan Selatan di situs http://www.kalselprov.go.id; bagaimana fungsinya sebagai lembaga komunikasi publik kepada warganya dan respons dari pemangku kepentingan utama terhadap kinerja komunikator pemerintah daerah dalam komunikasi pegawai negeri di pemerintah daerah mereka; serta layanan komunikasi melalui media offline lainnya.

Penelitian ini dilakukan pada kantor gubernur provinsi Kalimantan Selatan, khususnya pada struktur Biro administrasi pimpinan sekretariat pemprov dan sruktur Dinas kominfo pemprov kalsel. Selain itu juga dilakukan pada lokasi tertentu di propinsi Kalimantan selatan dimana ditemukan informan kunci yang bisa memberikan informasi dan penjelasan terkait dengan masalah atau pertanyaan penelitian ini. Waktu pelaksanaan penelitian di lapangan dan di tempat tempat studi kepustakaan berlangsung dari bulan januari sampai oktober 2020.

Informan dipilih berdasarkan kreteria yang sudah ditentukan, kemudian dari informan sebelumnya didapatkan informan berikutnya untuk memenuhi data yang diperlukan. Jika data yang diperoleh sudah jenuh, maka pencarian data bisa dihentikan berarti tidak diperlukan lagi informan berikutnya.

\section{HASIL DAN PEMBAHASAN}

Hasil penelaahan penulis terhadap konten komunikasi pemerintahan melalui media online dan offline, didapatkan simpulan bahwa komunikasi melalui dua kelompok media ini, belum punya relevansi dengan pemangku kepentingan masyarakat menengah kebawah, dan menunjukkan bentuk komunikasi yang terjadi bersifat downward communication. Hal ini menunjukan bahwa komunikasi pemerintah daerah melalui kedua media tersebut, belum responsif, transparan, akuntabel, dan terbuka.

Selain itu itu peneliti juga telah melakukan wawancara dengan 7 (tujuh) orang keys informan, yang mempunyai latar belakang beragam. Mereka itu mewakili akademisi, pedagang kaki lima, 
pengamat gender, serta informan yang berprofsei sebagai pengusaha/penerbitan/kontraktor, wartawan, politisi partai, dan pengamat komunikasi pemerintahan. Data kualitatif yang diperoleh dari keys informan ini, disajikan dan dianalisis. Wawancara dilakukan dengan mereka untuk mendapatkan data atau informasi, terkait dengan efektivitas komunikasi pemerintahan yang dilancarkan oleh pemprov kal sel, baik melalui media offline maupun online kepada stakeholdernya.

Dari wawancara dengan informan (AI) seorang wiraswastawan didapatkan data atau informasi bahwa komunikasi pemerintahan yang dilancarkan pemrov kal sel, melalui dinas perindustrian dan perdagangan tentang bantuan modal kepada UKM dan pelatihan ternyata menurut pengakuan yang bersangkutan tidak mengetahuinya. Sedangkan informasi tentang kebijakan pemprov yang tidak terkait dengan ekonomi, yakni tentang kelangkaan BBM dan Listrik PLN yang byarpet, pernah terbaca di suratkabar, tapi informasinya kurang memuaskan, karena kebijakan tersebut tidak bisa direalisir dilapangan. Informan (AI) berkata,

Saya belum pernah tahu adanya pemberitaan atau informasi dari dinas diperindag kalsel tentang adanya bantuan modal untuk UKM dan pelatihan yang di selenggarakan oleh Dinas tersebut. Yang pernah saya baca di surat kabar adalah pemberitaan kebijakan pemprov kal sel tentang kelangkaan BBM dan listrik PLN yang byarpet. Tapi kurang puas, karena kebijakan tersebut tidak bisa direalisir di lapangan. Saya berpikir mungkin karena BBM dan PLN dikelola oleh BUMN.

Sebetulnya informasi yang dibutuhkan oleh masyarakat adalah pemberitaan yang terkait langsung dengan aktivitas sehari hari (Kelangkaan BBM, Listrik Byarpet, kemacetan lalulintas) dan yang terkait usahanya (modal, pelatihan, dan perbankan). Informasi semacam ini cenderung dibutuhkan oleh masyarakat menengah kebawah. Entah kebetulan atau memang sengaja, pesan-pesan semacam itu, umumnya tidak dijelaskan secara tuntas. Salah seorang informan yang lain yakni (S) seorang jurnalis mengatakan hal tersebut,

Wartawan tidak bisa kritis, bisa bertanya tetapi tidak semuanya berkenan dijawab atau kalau dijawab juga tapi diminta jangan dimuat, misalnya anggaran yang ada dalam kebijakan, seperti program pemugaran rumah, tak pernah dikupas habis misalnya bagaimana pelaksan anya, tanggung jawabnya efektif atau tidak dan sebagainya. Berita semacam ini dikatakan mereka sensitif, sebagai alasan pembenar untuk mempersuasi wartawan agar mengikuti keinginanya.

Selain itu komunikasi pemerintahan yang dilancarkan oleh pemprov, disampaikan kepada sasaran yang kurang tepat, hal ini tercermin dari kurang relevannya antara materi yang disampaikan dengan yang diundang, serta pelaksanaan kegiatan. Materi yang didesiminasikan tentang pembelaan kepentingan perempuan tapi yang diundang adalah pejabat pemerintah, elite elite ormas dari atas sampai tingkat kelurahan dan desa. Sementara para perempuan di desa dan kelurahan tidak tersentuh oleh kegiatan tersebut. Salah seorang informan (SH) pengamat masalah gender mengemukakan pendapatnya,

Komunikasi Pemprov Kalimantan
selatan menurut saya kurang responsif
terhadap persoalan perempuan di Kal
sel, hal ini terlihat dari KDRT yang
terjadi terus meningkat. Pemprov mungkin
mengakui komunikasi dan usaha mereka
sudah maksimal, seperti edukasi melalui
sosialisasi yang diberikan oleh dinas PPA,
akan tetapi menurut saya edukasi itu
tidak/belum bisa menyentuh masarakat
lapisan bawah, karena kegiatan
tersebut diadakan di hotel berbintang
dan dihadiri oleh perwakilan
dinas-dinas, tokoh tokoh masyarakat
kelas atas yang belum juga pesan ini
sampai ke masyarakat bawah melalui
ormas yang hadir.

Kelemahan komunikasi pemerintah provinsi Kalimantan selatan, mungkin tidak terlepas dari kelemahan yang disinyalir dimiliki oleh pemerintah pusat. Pada suatu kesempatan juru bicara presiden Johan Budi dan Dirjen Informasi dan komunikasi Publik kementerian komunikasi dan informasi menyebut komunikasi pemerintah pusat belum terkoordinasi dan terkonsolidasi dengan baik. Dalam forum Bakohumas tanggal 24 agustus 2019 di Jakarta Johan Budi sel ku Juru bicara presiden menyampaikan pernyataan bahwa "cara pemerintah pusat dalam berkomunikasi kepada publik menjadi kritikan tajam akhir-akhir ini. Selain pernah terjadi kegaduhan antar Menteri dan pejabat negara diranah public,belakangan juga terjadi ketidaksamaan informasi". Sedangkan Dirjen informasi dan komunikasi public kementerian Kominfo, Niken Widiastuti menyebutkan bahwa "persepsi public terhadap informasi dari pemerintah juga menjadi salahsatu masalah yang perlu segera ditindaklanjuti”.

Ditingkat pemerintah provinsi Kalimantan selatan kelemahan komunikasi publik ini juga disinyalir, tidak luput dari kebijakan dibidang humas yang tidak sepenuhnya mempercayai kemampuan lembaga yang ada, disamping kelemahan SDM yang tergabung dalam lembaga 
tersebut. Hal ini tercermin dari pandangan informan (MA) seorang pengamat komunikasi pemerintahan berikut ini,

Kebijakan pemprov tidak bisa disampaikan dengan baik kepada stakeholder Disebabkan oleh beberapa faktor: Pertama, kompetensi pegawai masih kurang, seperti dalam hal membuat dan menganalisis berita. Kedua, sikap pimpinan kurang mendukung kemampuan pengelolaan pemberitaan. Dalam artian, kurang difungsikan untuk menganalisis dan memberi tanggapan berita. Ketiga, koordinasi antar SKPD lemah. Keempat, irama kerjanya rutinitas. Dalam artian melanjutkan yang sudah dilakukan oleh pejabat dan staf humas sebelumnya.Kelima, manajemen Humas kurang jalan.

Hal yang sama tampaknya dirasakan oleh informan (S) seorang jurnalis yang melihat komunikasi pemerintahan pemprov kalsel belum berjalan dengan baik, fungsi humas belum dipraktekan secara utuh. Bahkan dari segi kelembagaan saja, belum memenuhi kapasitas yang layak, misalnya kelembagaan humas harus di level atas. Informan (S) mengemukakan opininya,

Komunikasi pemerintahan pemprov kalsel yang saat ini digawangi( oleh biro Adpim dan dinas kominfo) harusnya agresif, aktif ketika ada pemberitaan miring. Atau sigap ketika ada wartawan konfirmasi pemberitaan. Kegiatan Humas saat ini belum mencerminkan fungsi secara utuh. Maksudnya, fungsi kegiatan komunikasi pemerintahan itu bukan sekedar menyampaikan, melainkan juga mengelola berita. Antara lain mengkoordinir berita SKPD, mengolah dan menyampaikannya ke media/wartawan

Perkembangan teknologi komunikasi dan informasi yang demikian pesat dan cepat, diikuti juga oleh pemerintah provinsi Kalimantan selatan, dengan membangun sebuah website, yang diberi nama "Website Resmi Pemerintah Provinsi Kalimantan Selatan" dengan URL http://www.kalselprov.go.id/\# . Meskinya website ini sangat strategis untuk menyampaikan komunikasi pemerintahan ke public, dan juga untuk menerima masukan serta aspirasi dari ma syarakat. Fungsi strategis ini nampaknya belum bisa diraih sepenuhnya oleh lembaga pemerintahan ini. Informan (S) seorang jurnalis, mengomentari hal ini dan menilai website pemprov kal sel belum begitu fungsional. Dia menyatakan opininya sebagai berikut,

Keberadaan website pemprov terkesan datar, tidak diupload setiap hari (membuat wartawan malas membukanya), kurang familiar (tidak begitu dikenal), isinya umum (profil lembaga, pejabatnya, tidak ada tentang kebijakan, kurang tersedia mekanisme interaktif di dunia maya), tidak bisa minta tanggapan.

Dari uraian uraian di atas diperoleh gambaran komunikasi pemerintah provinsi kalimantan selatan saat ini belum begitu fungsional, jalan dengan banyak kelemahan, yang tentunya berdampak pada citra pemprov sendiri dan pelayanan komunikasi pemerintahan yang terbatas. Terkait yang disebut terakhir, informan (W) seorang politisi partai politik, mengemukakan pendapatnya,
Komunikasi pemprov ke media adalah pemberitaan pencapaian prestasi dan sosialisasi. Misal, gubernur bertemu dengan pejabat pusat di bandara (ini yang ditonjolkan), bukan follow upnya (apa yang diperoleh terkait dengan kebijakan tertentu). Begitu juga pemberitaan tentang reboisasi, kerusakan lingkungan, tidak ada pemberian $H G U$ kelapa sawit, tidak pernah menjadi headline

Dari analisis di atas dapat dideteksi beberapa kekurangan komunikasi pemerintah provinsi Kalimantan selatan kepada stakeholdernya. Selama ini komunikasi pemerintahan pemprov cenderung downward communication, karena itu perlu dikoreksi dengan memulai dilaksanakannya komunikasi dua arah. Sekarang ini sebetulnya lebih mudah untuk melakukannya, dengan adanya media sosial. Kemudian dikembangkan pula komunikasi pemerintahan melalui komunikasi sosial dengan sasaran publik tertentu. Salah seorang informan (SA) seorang akademisi menyarankan solusi untuk komunikasi pemerintahan pemprov kal sel yang lebih baik sebagai berikut,

Sosial media memiliki potensi yang cukup besar untuk turut berkontribusi dalam komunikasi publik pemerintahan. Sosial media memiliki kelebihan diantaranya memungkinkan adanya komunikasi dua arah antara masyarakat dan pemerintah. Melalui sosial media masyarakat dapat langsung merespon informasi yang disebarkan oleh pemerintah. Penggunaan sosial media menjadi salah satu strategi yang cukup efektif dalam membangun pola komunikasi publik pemerintah dan perubahan mindset strategi komunikasi di era digital saat ini, komunikasi publik pemerintah perlu beralih dari metode konvensional ke metode digital. Dan peningkatan komunikasi publik juga dilakukan melalui komunikasi sosial dengan ragam sosialisasi, aksi dan pelatihan secara berke sinambungan. 
Berbeda dengan saran di atas $(\mathrm{SH})$ pengamat masalah gender, melihat lebih efektif komunikasi pemerintahan dilancarkan diarahkan kepada masyarakat menengah kebawah sebagai sasarannya. Tidak diserahkan komunikasi tersebut kepada para elite yang di tatar di hotel berbintang, tetapi tidak dapat dipastikan mereka akan meneteskan pengetahuan yang diperolehnya ke bawah. Dengan mengambil contoh komunikasi pemerintahan tentang masalah gender dia mengatakan,

Untuk memastikan komunikasi sampai ke masyarakat kelas bawah, edukasi melalui sosialisasi jangan glamor dan gaungnya saja yang besar dilakukan di hotel hotel berbintang menghabiskan banyak uang, tapi pesan belum tentu sampai ke masyarakat kelas bawah. Jadi buat program yang benar benar menyentuh persoalan perempuan di masyarakat bawah.

\section{Komunikasi Pemerintahan Partisipatif}

Salahsatu unsur penting dari good governance adalah transparansi yang hanya bisa dicapai melalui komunikasi pemerintahan partisipatif. Transparansi berarti memberi informasi secara benar, jujur dan adil; partisipatif berarti masyarakat diikutsertakan memberi informasi dalam membuat kebijakan dan berjalannya control sosial; Informasi-informasi yang penting dalam good governance ialah informasi sektor publik berhubungan dengan penyelenggaraan pemerintahan, hukum, dan administrasi; informasi sektor dunia usaha yang berhubungan dengan pengembangan potensi ekonomi; dan informasi sektor sosial yang berhubungan dengan kegiatan kegiatan sosial dan ekonomi yang tidak dijangkau oleh institusi public dan bisnis.

Ada beberapa prasyarat yang perlu dipenuhi agar komunikasi pemerintah daerah sesuai dengan prinsip demokrasi partisipatif. Sejalan dengan prasyarat itu, beberapa penulis telah menunjukkan pentingnya keterbukaan pemerintah untuk keterlibatan publik (Lee \& Kwak, 2012), untuk menciptakan budaya transparansi (Bertot, JC, et al., 2010), transparansi dalam komunikasi pemerintah ( Fairbanks, Ploughman, \& Rawlins, 2007), dan keterlibatan politik media dan warga negara (Dahlgren, 2009). Tujuan transparansi yang lebih luas adalah untuk memastikan bahwa warga negara memahami bagaimana keputusan dibuat dan memiliki kesempatan untuk berpartisipasi dalam proses pengambilan keputusan (Cavoukian \& Mitchinson 2003).Ada dua sisi dari kontroversi mengenai layanan komunikasi pemerintah, di era desentralisasi dan demokratisasi regional dalam konteks Kalimantan Selatan, yaitu; (1) menuntut agar pemerintah benar-benar memberikan layanan kepada masyarakat; (2) tuntutan keterbukaan dan transparansi pemerintah dalam semua kebijakan publik. Ini benar benar diilustrasikan dalam hasil wawancara dengan pemangku kepentingan utama dari luar pemerintah.

Sistem komunikasi pemerintah daerah yang interaktif dan responsif di mana pejabat pemerintah selalu mengkomunikasikan kebijakan publik kepada publik dan di mana orang dengan mudah mengakses informasi dan memberikan umpan-balik tentang berbagai masalah yang mereka hadapi dan kebijakan yang tidak tepat sasaran. Kondisi ideal komunikasi pemerintah partisipatif seperti ini tampaknya masih terbatas pada harapan para pemangku kepentingan yang menjadi informan dalam penelitian ini.

Studi ini menunjukkan hasil yang menginspirasi bahwa teknologi komunikasi melalui jaringan resmi pemerintah daerah sebenarnya dapat menjadi media komunikasi pemerintah yang efektif jika memfasilitasi partisipasi dan keterlibatan masyarakat. Pendekatanpendekatan ini berhubungan dengan partisipasi dalam media dan melalui media. Partisipasi melalu media berfokus pada peluang untuk berpartisipasi dalam debat publik, dalam apa yang oleh sebagian orang disebut ruang publik, mengikuti pendekatan konsensus (dalam konsep Habermas, 1991) di mana setiap warga negara terlibat dalam proses demokrasi lokal.

Studi ini menunjukkan hal penting yang terjadi dalam transisi demokrasi di Indonesia pada abad ke-21 bahwa harapan publik terhadap praktik komunikasi pemerintah daerah telah berubah dari peran "pejabat" tradisional menjadi "mitra yang baik": merawat warga negara, memahami kebutuhan komunitas lokal, dan menawarkan solusi untuk masalah mereka. Inilah arti sebenarnya dari pendekatan komunikasi pemerintah partisipatif yang harus diadopsi oleh para pemimpin lokal dalam konteks negara kepulauan seperti Indonesia.

\section{PENUTUP}

Studi ini benar-benar menemukan bahwa praktik dan kinerja komunikator pemerintah daerah di Kalimantan Selatan belum sepenuhnya sesuai dengan harapan warga danmasyarakat dan tuntutan undang-undang di mana pemerintah diminta untuk mendengarkan aspirasi pemangku kepentingan dan masyarakat lokal.

Kesimpulannya, studi ini telah membantu para pemerhati untuk memahami bahwa kualitas komunikasi pemerintah daerah dipengaruhi oleh berbagai faktor baik manajemen maupun struktural. Meskipun faktor manajemen tetap penting, dalam kasus pemerintah daerah Kalimantan Selatan, faktor struktural lebih berpengaruh pada implementasi komunikasi pemerintah dalam layanan publik. Sementara komunikasi pemerintah belum melibatkan partisipasi aktif dari pemangku kepentingan lokal utama dan warga negara mereka, lebih banyak 
kepentingan elit atau kepentingan partai daripada kepentingan publik atau kepentingan warga negara. Para pejabat pemerintah daerah kurang responsif dan masih downward communication, sehingga ide-ide profesionalisasi komunikasi pemerintah daerah masih terbatas pada harapan daripada kenyataan.

Mungkin bijaksana bagi pemerintah daerah di Kalimantan Selatan untuk meningkatkan kapasitas dan kualitas layanan komunikasi pemerintah kepada warganya melalui berbagai saluran, formal dan informal. Pemegang jabatan perlu mengembangkan komunikasi pemerintah daerah yang dialogis dan transparan dengan keterlibatan aktif oleh warga dan untuk mengadopsi pendekatan komunikasi pemerintah yang partisipatif. Studi ini merekomendasikan bahwa komunikasi pemerintah daerah dapat efektif jika memiliki visi dan misi pemberdayaan masyarakat dan keterlibatan warga negara dalam partisipasi untuk perencanaan komunikasi dan implementasinya termasuk suara dan perspektif perempuan.

\section{E. DAFTAR PUSTAKA}

Abidin, Said Zainal, 2002. Kebijakan Publik, Cetakan ketiga. Jakarta, Penerbit: Suara Bebas

Abdullah, Aceng .2000. Press Relations. Bandung. Penerbit:PT Remaja Rosda

Astuty, Sri.2017.Komunikasi Bencana, Kearifan Lokal, dan Pemberdayaan.Prosiding Aspikom.Yogyakarta.Penerbit: Buku Litera

Anderson, B. R. O'G. (1990). Language and power: Exploring political cultures in Indonesia.Ithaca: Cornell University Press.

Antlöv, H. (1995). Exemplary centre, administrative periphery: Rural leadership and the new order in Java. Richmond: Nordic Institute of Asian Studies, Curzon Press.

Aspinall, E., \& Fealy, G. (eds.) (2003). Local power and politics in Indonesia: Decentralisation and democratization. Singapore: Institute of Southeast Asian Studies

Aspinall \& G. Fealy (eds.), Local power and politics in Indonesia: Decentralisation and democratisation. Singapore: Institute of Southeast Asian Studies/Leiden: KITLV.

Aspinall, E. \& Mietzner, M. (eds.). Problems of democratisation in Indonesia: Elections, institutions and society. Singapore: ISEAS.

Berlo,D.K. 1960.The Process Communication.New York: Holt,Rinehart, and Winston

Bertot, J. C., et al. (2010). Using ICTs to create a culture of transparency: E-government and social media as openness and anti-corruption tools for societies.
Government Information Quarterly, 27(3).

Bimber, B. (2001). Information and political engagement in America: The search for effects of information technology at the individual level. Political Research Quarterly, 54(1), 53-67.

Buehler, M. (2012). Revisiting the inclusion-moderation thesis in the context of decentralized institutions: The behavior of Indonesia's Prosperous Justice Party in national and local politics. Party Politics, 19(2).

Buehler, M., \& Tan, P. J. (2007). Party-candidate relationships in Indonesian local politics: A case study of the 2005 regional elections in Gowa, South Sulawesi province. Indonesia, 84.

Bünte, M. \& Ufen, A. (eds.) (2009). Democratization in post-Suharto Indonesia. Oxon \& New York: Routledge.Canel, M. J. \& Sanders, K. (2010). Crisis communication and terrorist attacks: Framing a response to the 2004 Madrid bombings and 2005 London bombings. In Coombs, W. T. \& Holladay, S. J. (eds), Handbook of crisis communication. Hoboken, NJ: John Wiley $\&$ Sons.

Canel, M. J. \& Sanders, K. (2013). Introduction: Mapping the field of government communication. In Sanders, K. \& Canel, M. J. (eds.), Government communication: Cases and challenges. London: Bloomsbury.

Canel, M. J. \& Sanders, K. (2012). Government communication: An emerging field in political communication research. In Semetko, H. A. \& Scammell, M. (eds.) The Sage handbook of political communication. London: Sage.

Canel, M. J. \& Sanders, K. (2014). Is it enough to be strategic? Comparing and defiing professional government communication across disciplinary filds and between countries. In Canel, M. J. \& Voltmer, K. (eds.), Comparing political communication across time and space: New studies in an emerging fild. Basingstoke: Palgrave Macmillan.

Canel, M. J., \& Sanders, K. (2011). Government Communication. In International Encyclopedia of Communication Online, Wiley Blackwell.

Carpentier, N. (2011). Media and participation. Chicago: Intellect.

Cavoukian, A., \& Mitchinson, T. (2003). Making municipal government more accountable: The need for an open meetings law in Ontario. IPC Perspectives (October). 
Chernov Hwang, J. (2010). When parties swing: Islamist parties and institutional moderation in Malaysia and Indonesia, South East Asia Research, 18.

Choi, N. (2004). Local elections and party politics in post-reformasi Indonesia: A view from Yogyakarta. Contemporary Southeast Asia, 26(2).

Coe, K., \& Reitzes, M. (2010). Obama on the stump: Features and determinants of a rhetorical approach. Presidential Studies Quarterly, 40(3), 391-412.18

Dahlgren, P. (2009). Media and political engagement: Citizens, communication, and democracy. Cambridge: Cambridge University Press.

Daud, A. (1997). Islam dan masyarakat Banjar: Deskripsi dan analisa kebudayaan Banjar. Jakarta: Rajawali Press.

Daud, A. (2004). Islam dan asal-usul masyarakat Banjar. Kandil, 6(II), August-October. Deutsch, K. W. (1963). The nerves of government: Models of political communication and lcontrol. New York: Free Press.

Fairbanks, J., Plowman, K., \& Rawlins, B. (2007). Transparency in government communication. Journal of Public Affairs, 7(1), 23-37.

Fang, Z. (2002). E-Government in digital era: Concept, practice and development. International Journal of the Computer, $10(2), 1-22$.

Farnsworth, S. J. (2009). Spinner in chief: How presidents sell their policies and themselves. Boulder, CO: Paradigm.

Fatchiati, N. (2009). Budaya sungai dan patronase wilayah. Kompas, 17 February.

Fatchiati, N. (2009). Hasil pemilu Kalimantan Selatan: Kukuhnya patronase ketokohan. Kompas, 4 June.

Fatchiati, N. (2009). Peta politik Kalimantan Selatan: Bubuhan, benang merah urang Banjar. Kompas, 17 February.

Figenschou, T. U., Karlsen, R., Kolltveit, K., \& Thrbjørnsrud, K. (2017). Serving the media ministers: A mixed methods study on the personalization of ministerial communication. International Journal of Press/Politics, 22(4), 411-430.

Fionna, U. (2011). The pull and push between central and local political parties: A case study of party branch organisation in Indonesia. Asia Pacific Journal of Public Administration, 33(2).

Firmansyah,Hairi. Mira Yulianti. Muhammad Alif. 2017. Strategi Komunikasi dalam Pengua Tan Kapasitas Kelembagaan pada Pengelolaan Lahan Gambut melalui Peningkatan SDM di Sektor Pertanian Kalimantan Selatan.Prosiding Seminar
Nasional Lahan Basah. LPPM ULM tahun 2016

Gao, X. \& Lee, J. (2017). E-government services and social media adoption: Experience of small local governments in Nebraska state. Government Information Quarterly, 34(4), 627634. Geertz, C. (1973).The Interpretation of cultures: Selected essays. New York: Basic Books Ghazali, W.N.W.M. (2019). Islam as the state ideology: Exploring from Gramsci's notion of power, culture and ideology. Jurnal Komunikasi: Malaysian Journal of Communication,35(1).

Graham, M. W., et al. (2015). The role of social media in local government crisis communications. Public Relations Review, 41(3), 386-394.

Graham, S. \& Aurigi, A. (1997). Virtual cities, social polarisation, and the crisis in urban public space. Journal of Urban Technology, 4(1), 19-52.

Habermas, J. (1991). The public sphere. In Mukerji, C. \& Schudson, M. (eds.), Rethinking popular culture: Contemporary perspectives in cultural studies. Berkeley/Los Angeles: University of California Press.

Hadiz, V. R. (2010). Localising power in post-authoritarian Indonesia: A Southeast Asia

perspective. Stanford, CA: Stanford University Press.

Hansson, S. (2015). Discursive strategies of blame avoidance in government: A framework for analysis. Discourse \& Society, 26(3), 297-322.

Hansson, S. (2017). Anticipative strategies of blame avoidance in government: The case of communication guidelines. Journal of Language and Politics, 16(2), 219-241.19

Hansson, S. (2018). Government communication. In Wodak, R. \& Forchtner, B. (eds.), The Routledge handbook of language and politics. London \& New York: Routledge.

Hofman, B. \& Kaiser, K. (2002). The Making of the big bang and its aftermath: A political economy perspective, Paper Presented at the Conference 'Can decentralization help rebuild Indonesia?'. Atlanta: Georgia State University.

Hooker, V. M. (ed.) (1993). Culture and society in new order Indonesia. Kuala Lumpur: Oxford University Press.

Harjana,Andre.1993. Perbandingan Pola Strategi Komunikasi Penunjang Proses Industrialisasi Dunia Ketiga. Jurnal Ikatan Sarjana Komunikasi Indonesia.No 5 \& 6.Jakarta. Penerbit Kerjasama Iski-PT Gramadia Pustaka Utama. 
Hasan, Erliana .2005. Komunikasi Pemerintahan. Bandung, Penerbit: PT Refika Aditama

Ibrahim, Idi Subandy.2007. Kecerdasan Komunikasi (seni Berkomunikasi Kepada Publik), Bandung. Penerbit: Simbiosa Rekatama Media

Irwanto .2006.. Focused Group Discussion.Jakarta.Yayasan obor Indonesia

Ibrahim, I. S., (2011). Kritik budaya komunikasi: Budaya, media, dan gaya hidup dalam proses demokratisasi di Indonesia. Yogyakarta: Jalasutra.

Ipsos (2008). The reputation of local government: Literature review to support my council campaign. Retrieved on 10 November 2018 from www.ipsos-mori. com/researchpublications/publications/124 8/The-reputation-of-localgovernment.aspx

Jackson, K. D. (1978). The political implications of structure and culture in Indonesia. Berkeley: University of California Press.

Muthahhari, M. R. (2020). Jaringan Komunikasi Politik yang Dipilih Kepala Daerah dalam Proses Perumusan RAPBD Kota Banjarbaru Tahun 2019. ETTISAL: Journal of Communication, 5(1).

Rakhmat, J., \& Ibrahim, I. S. (2018). Metode penelitian komunikasi: Edisi revisi. Bandung: Simbiosa.

Rakhmat Jalaluddin .1984. Metode Penelitian Komunikasi. Bandung. Penerbit: Remadja Karya CV

Rawali, S., \& Ramadhani, M. M. (2021). The role of marketing communications of the banjar district government in improving the ecotourism image of the riam kanan reservoir south kalimantan, indonesia. European Journal of Management and Marketing Studies, 6(2).

Rogers, Everett M. and F.Floid Shomaker .1971.Communication

Of Innovation.Second Edition. New York London: The Free Press, Collier Macmillan .
Susanto, Astrid. 1989.Komunikasi Pengendalian Dan Komunikasi Pengawaan.Jakarta. Penerbit: Pustaka Sinar Harapan.

Saverin,J. Tankard. 1992. Communication Theories: Origins, Methods, and uses In The Mass Media. By Longman Publishing Group

Sanders, K. (2011). Political public relations and government communication. In Strömbäck, J. \& Kiousis, S. (eds.), Political public relations: Principles and applications. New York: Routledge.

Sanders, K., Canel, M. J., \& Holtz-Bacha, C. (2011). Communicating governments: A three cuntry comparison of how governments communicate with citizens. The International Journal of Press and Politics, 16(4), 523-47.

Supriatma, A. M. T. (2009). Menguatnya kartel para "bos". Prisma, 28(2).

Suryadinata, L. (2002). Elections and politics in Indonesia, Singapore: Institute of Southeast Asian Studies.

Ufen, A. (2011). Direct local elections and the fragmentation of party organization in Indonesia. APSA 2011 Annual Meeting Paper.

Vos, M. \& Westerhoudt, E. (2008). Trends in government communication in the Netherlands. Journal of Communication Management, 12(1).

Wilcox, Dennis L. Phillip H.Ault. Warren K.Agee.2011. Public Relations. Tangerang Selatan Karisma Publising Group

Wahid, U. (2013). Perempuan dan kekuasaan politik dalam pemilukada DKI Jakarta tahun 2012. Jurnal Komunikasi: Malasysian Journal of Communication, 29(1).

Young, S. (ed.) (2007). Government communication in Australia. Cambridge: Cambridge University Press. 